\title{
MEMOIR
}

\section{W. H. BISHOP 1923-1974}

Marcus William Hugh Bishop died suddenly on 15th June 1974 at the early age of 51 in the middle of a busy and productive professional career.

He was born in Cambridge in 1923, the son and grandson of farmers, and spent much of his free time during his youth on the family farms. After schooling at Cambridgeshire High he won an Open Exhibition to St Catherine's College, Cambridge, graduating B.A. in 1946 and M.A. in 1949. He obtained the Diploma of Agricultural Science also in 1949. His thesis for the Ph.D., conferred in 1955, was on The Physiology of Bull Spermatozoa. He had 3 years of National Service as a Marine Biologist (Scientific Officer) in the employment of the Iron and Steel Institute and the British Iron and Steel Research Association at the Marine Station, Millport, and then in 1949 he became a Scientific Officer at the A.R.C. Animal Research Station, Cambridge. Here he was supervised by Dr Arthur Walton for whom, as for the Director of the Station, Dr (later Sir) John Hammond, he developed a deep affection and esteem. After a little over a year's study leave on a Fulbright Scholarship at the University of Illinois, he held a research post at the National Institute for Medical Research, London, for 3 years and a Lectureship in the Department of Physiology at the Royal Verterinary College, London, also for 3 years. In 1962 he moved to the University of Bristol becoming Lecturer in Animal Reproduction in the Department of Animal Husbandry, and in 1970 he was appointed to the Readership in this Department.

Marcus Bishop's first major research contributions were made during his National Service appointment on the biology of organisms responsible for shiphull fouling and corrosion, and the sensitivity of various species to copper and mercury poisons, assisting thus in the development and testing of protective paints. This work led on to a specific interest in the biology and ecology of barnacles, especially the Australasian species, Elminius modestus, which he was the first to identify in British waters, and he traced the spread of this organism along the coasts of France and Spain.

The greater part of his research activities, however, was devoted to problems of male reproduction and fertility in mammals, and he is known particularly for his painstaking and detailed investigations on the characteristics of bull semen and their relation to fertility, on various aspects of sperm physiology and biochemistry, and on the morphological changes associated with penetration of the spermatozoon into the egg. He was the first to recognize the altered form of the hamster sperm head after passage through the zona pellucida and this observation cleared the way for a considerable research effort by many investigators on the mammalian acrosome reaction.

In later years, Bishop gave more attention to the genetic aspects of infertility and he made a perspicacious study of factors responsible for embryonic anomalies and birth defects, especially in domestic animals. 
He was a Foundation Member of the Society for the Study of Fertility and had the welfare of the Society very much at heart; he served for 10 years on the Committee, being Conference Secretary for the Annual Conference in Bristol in 1969. He was a referee for a number of years for the Fournal of Endocrinology and the Fournal of Reproduction and Fertility, and he edited Volumes 5 and 6 of Advances in Reproductive Physiology. In academic life he gave unsparingly of his time for teaching, both at the Royal Veterinary College and at the University of Bristol.

As a man Marcus will be remembered for his wide range of interest and comprehension, for his perfectionism so that he strove always for high standards (often with scant respect for publication dates), for his warm personal concern for people irrespective of social status or scientific prowess, for his loyalty to friends, and for his boundless enjoyment of good company.

Cambridge 1975

C.R.A.

\section{PUBLICATIONS}

1945

Perilitus coccinellae (Schrank) (Hymenoptera Braconidae) in Cambridgeshire. (with J. W. Bryden.) Entomologist's mon. Mag. 81, 51-52.

1946

Notes on the biology and sensitivity to copper and to mercury of tubeworms occurring as fouling organisms at Millport. Report N13/46 of the Marine Corrosion Sub-Committee.

Second report on the seasonal settlement of fouling organisms at various exposure sites. Report N10/46 of the Marine Corrosion Sub-Committee.

1947

The seasonal settlement of sedentary marine organisms on submerged panels. Abstract No. 125, Section D, British Association, Dundee.

Establishment of an immigrant barnacle in British Coastal waters. Nature, Lond. 159, 501-502.

Ship fouling. Abstract of paper read to the Challenger Society for the Study of Oceanography. Challenger Society, 2, No. 19.

Service tests of experimental anti-fouling compositions. (with $\mathrm{H}$. Barnes and $\mathrm{K}$. A. Pyefinch.) F. Iron Steel Inst. 157, 429-446.

The fouling occurring on ships in service. Report of the Marine Corrosion Sub-Committee.

1949

The examination and interpretation of fouling samples from ships. (with $\mathrm{K}$. A. Pyefinch and M. F. Spooner.) J. Iron Steel Inst. 161, 35-40.

1950

Distribution of Balanus amphitrite Darwin, var. denticulata Broch. Nature, Lond. 165, 409-410.

Fungoid infection in Ectocarpus granulosus. Nature, Lond. 165, 937.

\section{1}

The distribution of barnacles by ships. Nature, Lond. 167, 531 . 
1952

The effect of sperm concentration and dilution on the respiratory activity of bull semen. (with G. W. Salisbury.) Abstract of paper read to the American Dairy Science Association. F. Dairy Sci. 35, 490. Impedance change frequency in bull semen. (with R. G. Campbell and J. L. Hancock.) Abstract of paper read to the American Dairy Science Association. 7. Dairy Sci. 35, 491.

1953

Semen characteristics and fertility in the bull. (with R. C. Campbell and J. L. Hancock.) Abstract of paper read to a Ciba Foundation Symposium. In Mammalian Germ Cells, p. 103. J. \&. A. Churchill Ltd, London.

Elminius modestus in France. Nature, Lond. 173, 1145.

Semen characteristics and fertility in the bull. (with R. C. Campbell, J. L. Hancock and A. Walton.) 7. agric. Sci., Camb. 44, 227-248.

Effects of glycine on the survival of bull spermatozoa in vitro. (with A. Roy.) Nature, Lond. 174, 746-747.

Some aspects of the dilution effect in mammalian spermatozoa. Stud. Fert. 6, 81-95.

\section{5}

The effect of sperm concentration on the oxygen uptake of bull semen. (with G. W. Salisbury.) Am. $\mathcal{J}$. Physiol. 180, 107-112.

The effect of dilution with a yolk-containing extender on the oxygen uptake and motility of bull spermatozoa. (with G. W. Salisbury.) 7. Dairy Sci. 38, 202-207.

The effect of dilution with saline and phosphate solutions on the oxygen uptake of bull semen. (with G. W. Salisbury.) Am. F. Physiol. 181, 114-118.

The evaluation of bull semen. (with J. L. Hancock.) Vet. Rec. 67, 363-372.

Glycine-egg-yolk semen diluents. Vet. Rec. 67, 459.

Inter-relationships of semen characteristics. Stud. Fert. 7, 48-65.

\section{7}

The Australasian barnacle, Elminius modestus, in France. (with D. J. Grisp.) Nature, Lond. 179, 482-483.

Sur l'ecologie des cirripèdes de la cote atlantique française. (with D. J. Crisp, E. Fischer-Piette and M. Prenant.) Bull. Inst. océanogr. Monaco 54, No. 1099.

The physiology of bull spermatozoa. In abstracts of dissertations approved for the Ph.D., M.Sc. and M.Litt. degrees in the University of Cambridge during the academical year 1954-1955, pp. 1-2. Cambridge University Press.

Induced fluorescence in mammalian gametes with acridine orange. (with J. Smiles.) Nature, Lond. 179, 307-308.

Differentiation between living and dead spermatozoa by fluorescence microscopy. (with $\mathrm{J}$. Smiles.) Nature, Lond. 179, 308.

Preliminaries to fertilization in mammals. (with C. R. Austin.) In The Beginnings of Embryonic Development. Eds A. Tyler, R. G. von Borstel \& C. B. Metz. Publication No. 48. American Association for the Advancement of Science, Washington, D.G.

Fertilization in mammals. (with C. R. Austin.) Biol. Rev. 32, 296-346.

Mammalian spermatozoa. (with G. R. Austin.) Endeavour 16, 137-150.

\section{8}

The distribution of Elminius modestus Darwin in France. (with D. J. Crisp.) Proc. zool. Soc. Lond. 131, 109-134.

Capacitation of mammalian spermatozoa. (with C. R. Austin.) Nature, Lond. 181, 851.

Some features of the acrosome and perforatorium in mammalian spermatozoa. (with C. R. Austin.) Proc. $R$. Soc. B, 149, 234-240.

Role of the rodent acrosome and perforatorium in fertilization. (with G. R. Austin.) Proc. R. Soc. B, $149,241-248$. 
1959

The chemical composition of bull semen with special reference to nucleic acids, free nucleotides and free amino acids. (with P. M. Bhargave and T. S. Work.) Biochem. 7. 73, 242-247.

Incorporation of ${ }^{14} \mathrm{C}$-amino acids into the proteins of bull spermatozoa. (with P. M. Bhargava and T. S. Work.) Biochem. 7. 73, 247-256.

Differential fluorescence in living rat eggs treated with acridine orange. (with C. R. Austin.) Expl Cell Res. 17, 35-43.

Presence of spermatozoa in the uterine-tube mucosa of bats. (with G. R. Austin.) F. Endocr. 18, viii-ix. Prevention of freezing damage to living cells by dimethyl sulphoxide. (with J. E. Lovelock.) Nature, Lond. 183, 1394-1395.

1960

Spermatogenesis and the individuality of the spermatozoon. In Sex Determination and Differentiation. Mem. Soc. Endocr. 7, 81-92.

Spermatogenesis and the structure of mammalian spermatozoa. (with A. Walton.) In Marshall's Physiology of Reproduction, 3rd edn, Vol. 1, part 2, Chapter 7, pp. 1-129. Ed. A. S. Parkes. Longmans Green, London.

Metabolism and motility of mammalian spermatozoa. (with A. Walton.) In Marshall's Physiology of Reproduction, 3rd edn, Vol. 1, part 2, Chapter 9A, pp. 264-309. Ed. A. S. Parkes. Longmans Green, London.

Suspension of life by freezing and drying. New Scientist 7, 1296.

1962

Steak from sawdust. In The Scientist Speculates, pp. 220-221. Ed. I. J. Good. William Heinemann Ltd, London.

1963

Differentiation of the acrosome in living mammalian spermatozoa and spermatids by fluorescence microscopy. F. Reprod. Fert. 6, 297-303.

\section{4}

Paternal contribution to embryonic death. F. Reprod. Fert. 7, 383-396.

Delayed implantation. (Book review.) Eugenics Rev.

Some observations on cryptoorchidism in the horse. (with J. S. E. David and A. Messervy.) Vet. Rec. 76, 1041-1048.

A case of amputate, a rare recessive lethal condition of Friesian cattle. Vet. Rec. 76, 1049-1053.

1965

An association between rainfall and sex ratio in man. (with W. R. Lyster.) 7. Reprod. Fert. 10, 35-47.

1966

The chemistry and physiology of the gametes. (with others.) Report of a WHO Scientific Group. World Health Organisation Technical Report Series, No. 333, 1-23.

Cryptorchidism in the stallion. (with J. S. E. David and A. Messervy.) Proc. R. Soc. Med. 59, 769-770.

1969

Possible explanations for the aberrant occurrence of boar-taint in female and castrated pigs. In Meat Production from Entire Male Animals, pp. 297-322. Ed. D. N. Rhodes. J. \& A. Churchill Ltd, London.

1970

Ageing and reproduction: the male and male germ cells. 7. Reprod. Fert., Suppl. 12, 65-87.

Reproductive expectancy and infertility in cattle. (with J. S. E. David and H. J. Cembrowicz.) Proc. 6th Int. Conf. Cattle Diseases.

Reproductive expectancy and infertility in cattle. (with J. S. E. David and H. J. Cembrowicz.) Vet. Rec. 89, 181-185. 